\title{
The Management of Students' Sense of Nationalism in Regular High School (SMA) and Islamic High School (MA) According to Their Gender
}

\author{
Yayat Suharyat ${ }^{1}$, Diyah Yuli Sugiarti ${ }^{2}$ \\ Faculty of Islamic Studies Universitas Islam “ 45 ” Bekasi, Indonesia ${ }^{1}$ \\ Postgraduate Universitas Islam "45" Bekasi, Indonesia ${ }^{2}$ \\ \{ suharyat unisma09@yahoo.com ${ }^{1}$, diyah.ys@gmail.com ${ }^{2}$ \}
}

\begin{abstract}
The purpose of this research is to show the differences in the degree of nationalism between students from regular high schools/Sekolah Menangah Atas (SMA) and students from Islamic high schools/Madrasah Aliyah (MA) according to their gender. This study is a piece of Export Facto research conducted at senior high school level in Bekasi city. The sampling method used a multistage random sampling technique. The data were analyzed using $2 \times 2$ variance analysis. The result shows that: 1) MA students have a higher sense of nationalism than SMA students, 2) female students' sense of nationalism is higher than male students'; 3) interaction between school type and gender has zero influence on sense of nationalism. This research suggests that to improve students' sense of nationalism, religious activities should be part of intracurricular and coaching programs in schools.
\end{abstract}

Keywords: Nationalism, Female Students, Male Students

\section{Introduction}

Every nation has its state symbols and banners, and its people are supposed to be proud of them. Those symbols and banners are not merely plastered on school walls or offices. They also have to be respected for the sake of glory and civilization above all other nations. Among such state symbols, Pancasila serves to become the state symbol and the ideological foundation of Indonesia. Presenting Pancasila as the foundation of the nation amid the life of the Indonesian people, by setting Garuda bird as the state emblem, is not an easy matter. It has involved a long and tiring process, lengthy debate and discussion ever since the founders of the nation formulated the nation's ideology[1], [2].

As the times progress and the conditions change, everyone starts to have the opportunity to search for a new piece of information regarding their nation's ideology. Even when they are not looking for it, such information lurks for anyone to find it, waiting to be accepted or denied. Furthermore, as the people's intelligence increases and their level of education elevates, two possible outcomes will ensue; they will either accept the concept and reasoning of their state ideology or denied them altogether. It even becomes more worrying when the concept in the state symbol is infiltrated by other tenets and religious dogmas, whereas the teachings of religion have never renounced Pancasila as the state ideology and foundation of 
the country. Indonesian history has shown proof of harmonization and integration among nation, state, and religion. It happened because the founders of this country were good and religious people. It is hard to believe that such respectable people would "sell" their religious beliefs only for momentary interests [1], [3], [4].

It can be said that the concept and reasoning in Pancasila as the state symbol and ideology is a result of enduring struggle and hard work of Indonesian spiritualists who held strongly onto their religion. The condition of the past is certainly very different from the present time. Nowadays, information technology has become ubiquitous and sophisticated. This study is certainly not intended to oppose the idea regarding the rapid growth and development of an information system. However, considering the derivation and distortion of understanding of the present generation regarding Pancasila, particularly of high school students, it is extremely important to empirically re-explore the young generation's acceptance of Pancasila in particular and their sense of nationalism in general [1], [3]-[5].

Subroto argues that as an ideology Pancasila is open, cooperative and very tolerant in addressing changes and progress throughout the times. Thus, it will not shut itself down in a static doctrine. It will constantly be changing, growing and getting rich with the nuances of a noble and glorious life according to the needs of the society. Similarly, Abimanyu states that Pancasila is elastic and implementable. It takes a comprehensive elucidation and a thorough illumination from all components of the nation so that it will still contain space full of great values and nobility [1], [2].

The core of the problem that occurs is not on the ideological principles but rather on the perspectives or responses of a person concerning the ideology. It will be very interesting to conduct an overall analysis of the intellectual absorption of an educated person, manifested in one's attitude when it comes to the ideology of their nation [1], [6].

According to Al Batawy, nationalism is a notion that creates and defends the sovereignty of a nation by embodying a concept of common identity for a group of people. Meanwhile, Henken suggests that nationalism is a centered view of one's nation. Therefore, nationalism has a positive sense; suggesting the idea of fighting for and defending the nation's independence and dignity as well as respecting other nations. In the context of Indonesia, nationalism is useful to foster a sense of unity among the population of the heterogeneous nation packed with differences in ethnicity, religion, and origin. It also serves to nurture a sense of identity and togetherness as fellow countrymen as well as to contribute to the nation's independence. About the social order, the growth and development of nationalism are influenced by both internal and external factors. Internally, the growth of nationalism in Indonesia is caused by the following factors: (a) the re-emergence of the middle class and the educated; (b) the suffering and misery experienced by all people in various spheres of life; (c) the groups of various descents; and (d) the desire to escape from imperialism. As for the external factors, the growth of nationalism in Indonesia is influenced by (a) modern European ideals (liberalism, humanism, nationalism, and communism); (b) Pan-Islamic Movement; (c) the movement of the colonized peoples of Asia, and (d) the victory of Russia over Japan [1], [3], [7], [8].

In the times of crisis, the symptoms toward the disintegration of the nation have come to light. Such disintegration began to emerge as a result of the crisis of trust, such as the crisis of trust from the local government toward the central government. To prevent such disintegration from widening and thus threatening national resilience, it is necessary to renew three values: firstly, the renewal of personal values; secondly, renewal of group values; and thirdly, the renewal of the nation's values[3], [7]-[9]. 
About that matter, the role of national education is of paramount importance. If the installments of the three values in today's youth appear to go very slow, one of the main reasons is that in school students may have never been taught to recognize values, to be aware of their personality and identity, and to develop egalitarian feelings within them as well as to avoid arrogance. So, if we wish to have a younger generation more superior in terms of values recognition, much clearer in terms of national identity, and more democratic and less arrogant than our generation, the national education must consciously focus on educating the young generation in that direction[1], [10].

Education should shape the students' hearts and feelings because values, identity, and egalitarian attitudes primarily deal with 'hearts' and affections, and not merely with cognitive knowledge. Schools should also try to teach the students to be able to control themselves, to be away from arrogance, and to avoid demeaning others. In other words, schools must consciously nurture students' sense of creations, affections, and intentions. Schools should conduct cognitive, effective, and conative coaching simultaneously[4], [6], [9], [11].

Educational institutions are the most strategic places for creating a generation that loves their homeland. This is because everyone in each educational institution has the same need and interest to create a reliable generation with strong character and spirit for developing their country. Every country relies on its strong, healthy, intelligent, and prosperous citizens. Conversely, every citizen is also responsible for and obliged to defend their country. Thus, the cultivation of nationalism, on the one hand, becomes the obligation of the government, but on the other hand, it is also a civic duty for every student to accept the system of teaching [8]$[10]$.

\section{Method}

This research uses Expost Facto method. It analyzes the data by using two-way variance analysis. Variables in this study consist of 1) independent variables which include: (a) type of school and (b) gender; and 2) a dependent variable, which is the sense of nationalism.

The independent variable of school type consists of two, namely: (1) regular high school (Sekolah Menengah Atas/SMA) and (2) Islamic high school (Madrasah Aliyah/MA). Meanwhile, the independent variable of gender is also divided into two, namely: (1) men and (2) women.

The study was conducted in some SMAs and MAs in the City of Bekasi. The time of the research started from March to June 2015. The research sampling was done by applying a multistage random sampling technique.

The data collection technique in this study used a particular research instrument. The instrument used in this research is an instrument for highlighting a sense of nationalism[12].

\section{Result and discussion}

Hypothesis testing is done by $2 \times 2$ variance analysis techniques. The results obtained are shown in the table below: 
Tabel 1.Tests of Between-Subjects Effects

\begin{tabular}{lrrrrr}
\multicolumn{7}{c}{ Dependent Variable: } \\
\hline \multicolumn{1}{c}{$\begin{array}{c}\text { Type III Sum of } \\
\text { Source }\end{array}$} & \multicolumn{1}{c}{$\begin{array}{c}\text { Mean } \\
\text { Squares }\end{array}$} & Df & \multicolumn{1}{c}{ Square } & \multicolumn{1}{c}{ F } & \multicolumn{1}{c}{ Sig. } \\
\hline Corrected Model & $355.650^{\mathrm{a}}$ & 3 & 118.550 & 69.638 & .000 \\
& 10428.017 & 1 & 10428.017 & 6125.548 & .000 \\
A & 198.017 & 1 & 198.017 & 116.317 & .000 \\
B & 176.053 & 1 & 176.053 & 103.364 & .000 \\
$\mathbf{A} * \mathbf{B}$ & .817 & 1 & .817 & .480 & .491 \\
Error & 95.333 & 56 & 1.702 & & \\
Total & 10879.000 & 60 & & & \\
Corrected Total & 450.983 & 59 & & &
\end{tabular}

a. R Squared $=.789$ (Adjusted R Squared $=.777$ )

The explanation for the results presented in the table above is as follows: 1) there is a difference in the degree of nationalism between SMA students and MA students. According to the result of hypothesis testing, it shows that $p$-value $=0,000<0.05$. To know which group has a higher sense of nationalism is simply done by looking at the mean score of both groups. The mean score of SMA students is 60,66 , while that of MA students is 65,16 . Thus, it can be concluded that the sense of nationalism in MA students is higher than in SMA students, 2) there is also a difference in the degree of nationalism between male students and female ones, according to the results of the hypothesis testing analysis which show that the $p$-value $=0,000$ $<0.05$. To know which group has a higher sense of nationalism is done by looking at the mean score of both groups. The mean score of the male students' sense of nationalism is 62.5 , while the mean score of female students' sense of nationalism is 63.4. Therefore, it can be concluded that female students have a higher sense of nationalism than male ones; 3) school type and gender have zero influence on the degree of nationalism. The results of the hypothesis testing show $\mathrm{p}$-value $=0.491>0.05$.

The analysis unfolded some results which will be discussed as follows: 1) sense of nationalism of MA students is higher than of SMA students. The sense of nationalism will develop if a process of instilling religious values takes place. Such reality occurs in Islamic educational institutions whose students have been proven to have a better understanding of nationality and possess a higher sense of nationalism than students from regular educational institutions. This condition is caused by several factors such as a) the coaching system which regulates students' activities in MA is administered directly by the school. Thus, the contents of the activities have been tested beforehand; b) the learning materials related to Islamic teachings in MA is better in terms of frequency and quality. The contents are so deep that they enable the students to acquire the knowledge needed for the management of self-perception; c) the students' activities, especially those related to religious beliefs, are constantly under the supervision of teachers who are appointed as the students' activity supervisors. So, the students always consult with the supervising teachers before the carrying out any religious activity in the school, d) the MA students come from groups of people who are culturally and 
structurally always supportive of and giving respect to the State and Nation, and e) the coaching system in MA is directly handled by the teachers, not by outsiders. The system is implemented within the schools so that the spirit and pattern of coaching are attached to the scope of intracurricular activities. 2) Female students have a higher sense of nationalism than male ones do. History shows that the success of nurturing character starts from family. This is where the role of a woman begins. A mother is the first teacher for her child. Affection, love, tolerance, and spirit in various spheres of life are the initial characters shaped in a family by a mother. The role of a mother is more easily transmitted to her daughter. As a result, the female students' degree of nationalism is higher than that of the male ones; 3 ) the interaction between school type and gender has zero influence on the sense of nationalism. This study reveals that both school type and gender have a great influence on the sense of nationalism. MA students, regardless of their gender, have a higher sense of nationalism compared to SMA students. In addition, in each type of school, female students have a higher sense of nationalism.

\section{Conclusion}

According to the result, it can be concluded as follows: 1) sense of nationalism of MA students is higher than that of SMA students, 2) sense of nationalism of female students is higher than that of male ones 3 ) interaction between school type and gender has zero influence on sense of nationalism.

About the conclusion, several suggestions can be proposed: 1) the schools are expected to develop a curriculum specific for intracurricular programs which incorporate the teachings of the love of homeland with nationhood through civics learning along with extra and cocurricular activities. For example, the schools can accommodate studies on how to defend the country combined with the program for developing social activities. Students should be given an opportunity to experience social activities which enables them to work together with the community. The activities should involve maintaining the spirit for loving the country and the nation. 2) the schools should carry out supervision and control to administer religious activities. The strategy is by placing a companion teacher acting as the mentor. This companion teacher should play a direct role in formulating the framework of activities and studies that are routinely done. With this strategy, every religious activity will be controlled under the direction of the school and will actually be able to support intracurricular programs particularly in relation to the management of civics and nationalism. 3) The educational process always takes place in the top down-bottom up the corridor. Therefore, a role model in educational practices is very important. Furthermore, the role of the education authorities in the cities and the districts should focus on conditioning the teachers to be able to provide opportunities for their students to explore the values of Pancasila, Nationalism and Nationhood in the form of workshops, seminars and many other programs, which are integrated in the academic affairs (learning process) and extracurricular activities. Until now, the role of teachers remains irreplaceable when it comes to setting good examples for students.

\section{References}

[1] A. Henken, Dimensi Nasionalisme dan Kebangsaan. Jakarta: Salemba, 1988.

[2] T. K. S. MPR, 4 Pilar Kehidupan Berbangsa dan Bernegara. Jakarta: Sekretariar Jenderal MPR RI, 2012.

[3] N. Al-Batawy, Umrah, Haji dan Komitmen Pembaruan Bangsa. Tangerang: Saluni, 
2014.

[4] M. Natsir, Agama dan Negara. Jakarta: Pustaka Dakwah, 2001.

[5] Sartono, Sejak Indische Sampai Indonesia. Jakarta: Kompas, 2005.

[6] S. Sagala and S. Gultom, Praktik Etika Pendidikan di seluruh wilayah NKRI. Bandung: Alfabeta, 2011.

[7] H. A. B. Almascaty, Panduan Jihad untuk Aktivis Gerakan Islam. Jakarta: Gema Insani Press, 2001.

[8] A. Tafsir, Filsafat Pendidikan Islami. Bandung: Remaja Rosdakarya, 2010.

[9] H. A. . Tilaar, Manajemen Pendidikan Nasional. Bandung: Remaja Rosdakarya, 2008.

[10] Rusman, Manajemen Kurikulum. Jakarta: Rajawali Pers, 2009.

[11] M. Emzir, Metodologi Penelitian Pendidikan. Jakarta: Rajawali Press, 2009.

[12] A. Aris Munandar, Gajah Mada Biografi Politik. Jakarta: komunitas Bambu, 2010. 